\title{
Ecological and health risk from heavy metal exposure to fish.
}

\author{
Olawusi-Peters $\mathrm{OO}^{1}$, Ajibare $\mathrm{AO}^{2 *}$, Akinboro $\mathrm{TO}^{1}$ \\ ${ }^{1}$ Department of Fisheries and Aquaculture Technology, Federal University of Technology, Akure, Nigeria \\ ${ }^{2}$ Department of Biological Sciences, KolaDaisi University, Ibadan, Nigeria
}

\begin{abstract}
Heavy metals in the gills and muscles of Sarotherodon galilaeus, Coptodon zilli, Heterobranchus isopterus and Clarias isherensis of Awara Reservoir, Ikare-Akoko Ondo State, Nigeria were assessed from February to May, 2016 using 210VGP Atomic Absorption Spectrophotometer after digestion and the values were subjected to Health Risk Index and Ecological Risk Quotient. Results revealed that the observed concentration of heavy metals was generally below the permissible limit. The trend of metal accumulation in the examined four fish species was $\mathbf{C d}<\mathrm{Cr}<\mathrm{Pb}<\mathrm{Cu}<\mathrm{Mn}<\mathrm{Zn}$, with zinc having the highest concentration in all four species. The bio-accumulation of metals was higher in family Cichlidae than the Claridae with $S$. galilaeus having the highest concentration. The gills bio-accumulated more metals than the muscles in all the species with the highest in $S$. galilaeus $(\mathrm{Zn}=0.598)$ and lowest in $C$. isherensis $(\mathrm{Cd}=0.007)$. Although Mn pose some level of ecological risk to $S$. galilaeus and $H$. isopterus, there was no health risk as the health risk index was below one (1). Hence, Awara reservoir is suitable for the survival of fishes and the species can be considered fit and safe for consumption. However, the fact that some levels of the examined minerals were found in the fishes calls for constant monitoring of the reservoir.
\end{abstract}

Keywords: Bio-accumulation, Food security, Sarotherodon galilaeus, Coptodon zilli, Heterobranchus isopterus, Clarias isherensis.

Accepted on October 09, 2019

\section{Introduction}

Fisheries are the most important element in the economy of many nations as they have been a stable item and a good protein source in the diet of many people. Fishes are bio-monitors of aquatic ecosystems especially in estimating pollution of heavy metals [1]. Heavy metals pollution in the aquatic environment is a globally increasing problem because they are highly persistent, indestructible and possess the ability to bio-accumulate [2].

Fishes are suitable indicators of heavy metal contamination and are extensively used to evaluate the health of aquatic ecosystem since they are of different sizes and occupy different trophic levels [3]. Since fishes are at the end of the aquatic food chain they reflect the water quality and are indicators of pollution. Metals in the aquatic environment accumulate in the food chain and lead to ecological damage as well as human health risks after eating such aquatic organism [4]. Hence, monitoring the contamination of fish tissue is important as early warning indicator of water quality contaminations [5] and helps taking rights actions in the interest of public health and the environment.

The quality of aquatic environment (including Awara reservoir) is being degraded as a result of anthropogenic activities. Since fish is important in human diet especially in the area, this study determined the concentrations of $\mathrm{Cd}, \mathrm{Cr}$, $\mathrm{Cu}, \mathrm{Mn}, \mathrm{Zn}$, and $\mathrm{Pb}$ in fishes of Awara water reservoir in IkareAkoko Ondo state, Nigeria and to provide a baseline information on the background levels, concentration pattern, ecological and health status of Sarotherodon galilaeus, Coptodon zilli,
Heterobranchus isopterus and Clarias isherensis in the aquatic ecosystem.

\section{Material and Methods}

\section{Study area}

Awara Reservoir in Ikare-Akoko, Akoko North-East Local Government Area of Ondo State Nigeria was built in 1956 to supply 6.7 million litres of portable water to the people of IkareAkoko and Akungba-Akoko in Akoko South-West and ArigidiAkoko in Akoko North-West area of the State. The Reservoir falls within Latitude $5^{\circ} 30^{\prime}$ and $6^{\circ} 00^{\prime}$ North and Longitude $7^{\circ} 30^{\prime}$ and $8^{\circ} 00^{\prime}$ East. It was constructed from River Asanodi whose tributaries are Oyimo River, Elemoro River and Awara River and a lot of agricultural activities are carried out in the immediate environment (United Nations Industrial Development Organization, 2013). The reservoir has a catchment area of $1.984 \times 10^{6} \mathrm{~m}^{2}$ and an undulating terrain with outcrops of rocks. The minimum and maximum flood discharge of the Reservoir is $0.0098 \mathrm{~m}^{3} / \mathrm{s}$ and $0.1607 \mathrm{~m}^{3} / \mathrm{s}$ respectively. The minimum and maximum water level of the Reservoir is $371.85 \mathrm{~m}$ and 379.85 $m$ respectively [6].

\section{Sample Collection and Identification}

Gill nets (ranging between $0.16 \mathrm{~mm}-3 \mathrm{~mm}$ ) were used to catch fishes monthly between $16.00 \mathrm{hrs}$ and $7.00 \mathrm{hrs}$ from February 2016 to May 2016 with the assistance of artisanal fishermen. The specimens were preserved in ice chest and transported to Fisheries and Aquaculture Technology Laboratory of the Federal University of Technology, Akure for sorting and 
identification. Fish samples were identified to species according to Adesulu and Syndenham [7] and Olaosebikan and Raji [8].

\section{Determination of heavy metals}

Adhering substances were removed from the fishes by rinsing with distilled water. Also the gill was separated from the muscle. The gills and muscles were separately oven-dried at $105^{\circ} \mathrm{C}$ for eight hours in a Gallenkamp moisture extraction oven. The samples were grounded into powder, homogenized and digested as described by Sani i.e. $5 \mathrm{~g}$ of each homogenized samples were weighed into a $200 \mathrm{ml}$ Kjeldahl digestion flask and digested with $20 \mathrm{ml}$ of mixed concentrated nitric acid and $62 \%$ perchloric acid (ratio 2:1) on a heater. Afterwards, the mixture was heated until the dense white fumes that indicated the disappearance of nitric acid appeared. The solution was further transferred to a $250 \mathrm{ml}$ volumetric flask that was subsequently made up to volume with deionized water and the metal concentrations in each sample were determined using AAS bulk (210VGP) according to AOAC, 2006 [9].

\section{Statistical analysis}

Multivariate analysis of variance was used to compare the concentration of heavy metals in the fish species $(\mathrm{P}=0.05)$ while T-test was used to compare the concentration in the gills and muscles ( $\mathrm{P}=0.05$ ), using Statistical Package for Social Sciences (16.0). Descriptive statistics was also used to present tables and figures.

\section{Risk characterization}

Risk characterization is the link between assessment of risks and its management. However, a risk characterization is incomplete without numerical expressions of risks; alongside comprehensive analysis interpreting and qualifying the values. A risk assessment index greater than 1 indicates a threat to the environment and human health [10].

\section{Ecological Risk Assessment (ERA)}

Concentration of chemicals above permissible limits in the aquatic media reveals high levels of ecological risks. These associated risks must be numerically evaluated for quantification and interpretation. ERA/ERQ was therefore calculated using the following equation:

$$
\text { Ecological Risk Quotient }=\frac{\text { Environmental Concentration }(\mathrm{mg} / \mathrm{kg})}{\text { Recommended Limit }(\mathrm{mg} / \mathrm{kg})}[10]
$$

\section{Health Risk Assessment (HRA)}

This gives a quantitative knowledge of risk that each contaminant poses to the health of the fish consumers. It was calculated as:

$$
\text { Health Risk Index }=\frac{\text { Daily Intake of Metal }(\text { DIM })}{\text { Reference Oral Dose }(R O D)}
$$

Where,

$$
\text { DIM }=\frac{M \times C F \times \text { Daily intake of fish }}{\text { Average body weight }}
$$

Where,

$\mathrm{M}$ is the concentration of metal in fish $(\mathrm{mg} / \mathrm{kg})$,

$\mathrm{CF}($ Conversion Factor $)=0.085$. (Note that $60 \mathrm{~kg}$ was adopted as the average body weight of the fish consumers. Daily intake of fish was also estimated as $48 \mathrm{~g} /$ person/day according to FAO, 2007 [11].

\section{Results}

The concentration of heavy metals in the gills and muscle of the species examined is presented in Table 1 . The concentration of metals were significantly different $(\mathrm{P}<0.05)$ across the four species and were below the WHO [12], FEPA [13] and FAO [11] permissible limits. The comparison between the concentration of heavy metals in the gills and muscle (Figure 1) shows that the concentration of metals in the four species were significantly higher $(\mathrm{P}<0.05)$ in the gills than in the muscle. Concentration of $\mathrm{Cu}$ in the gills ranged from $0.215 \pm 0.02 \mathrm{mg} / \mathrm{kg}$ in C. zilli to $0.260 \pm 0.02 \mathrm{mg} / \mathrm{kg}$ in $H$. isopterus, while $\mathrm{Cd}$ ranged from $0.007 \pm 0.01 \mathrm{mg} / \mathrm{kg}$ in C. isherensis to $0.013 \pm 0.00 \mathrm{mg} / \mathrm{kg}$ in $S$. galilaeus. The minimum concentration of $\mathrm{Cr}$ was $0.036 \pm 0.03$ $\mathrm{mg} / \mathrm{kg}$ in $H$. isopterus while the maximum concentration was $0.100 \pm 0.00 \mathrm{mg} / \mathrm{kg}$ in C. zilli. The highest mean concentration of $\mathrm{Pb}(0.185 \pm 0.03 \mathrm{mg} / \mathrm{kg})$ was recorded in C. zilli while the lowest mean concentration of $\mathrm{Zn}(0.486 \pm 0.21 \mathrm{mg} / \mathrm{kg})$ was recorded in $H$. isopterus. The concentration of $\mathrm{Mn}$ also ranged from $0.290 \pm 0.03 \mathrm{mg} / \mathrm{kg}$ in $C$. isherensis to $0.370 \pm 0.05 \mathrm{mg} /$

\begin{tabular}{|c|c|c|c|c|c|c|c|}
\hline Parts & Metals & C. isherensis & H. isopterus & S. galilaeus & C. zilli & $\begin{array}{l}\text { WHO, (2003)/ } \\
\text { FEPA, (2003) }\end{array}$ & FAO, (2007) \\
\hline \multirow{6}{*}{ Gills } & $\mathrm{Cu}$ & $0.223 \pm 0.02^{b}$ & $0.260 \pm 0.02^{\mathrm{d}}$ & $0.235 \pm 0.03^{c}$ & $0.215 \pm 0.02^{\mathrm{a}}$ & 3.00 & 3.00 \\
\hline & $\mathrm{Cd}$ & $0.007 \pm 0.01^{a}$ & $0.010 \pm 0.00^{b}$ & $0.013 \pm 0.00^{c}$ & $0.010 \pm 0.00^{\mathrm{b}}$ & 0.50 & 0.20 \\
\hline & $\mathrm{Cr}$ & $0.043 \pm 0.03^{b}$ & $0.036 \pm 0.03^{a}$ & $0.065 \pm 0.04^{c}$ & $0.100 \pm 0.00^{d}$ & 0.50 & 0.50 \\
\hline & $\mathrm{Pb}$ & $0.107 \pm 0.01^{a}$ & $0.133 \pm 0.04^{b}$ & $0.153 \pm 0.06^{c}$ & $0.185 \pm 0.03^{d}$ & 2.00 & 2.00 \\
\hline & $\mathrm{Zn}$ & $0.527 \pm 0.06^{b}$ & $0.486 \pm 0.21^{a}$ & $0.598 \pm 0.10^{d}$ & $0.553 \pm 0.03^{c}$ & 30.00 & 30.00 \\
\hline & $\mathrm{Mn}$ & $0.290 \pm 0.03^{a}$ & $0.370 \pm 0.05^{b}$ & $0.363 \pm 0.01^{b}$ & $0.300 \pm 0.00^{\mathrm{a}}$ & 0.50 & 0.50 \\
\hline \multirow{6}{*}{ Muscle } & $\mathrm{Cu}$ & $0.170 \pm 0.02^{d}$ & $0.160 \pm 0.12^{c}$ & $0.103 \pm 0.00^{a}$ & $0.125 \pm 0.02^{b}$ & 3.00 & 3.00 \\
\hline & $\mathrm{Cd}$ & $0.000 \pm 0.00^{a}$ & $0.004 \pm 0.00^{b c}$ & $0.005 \pm 0.01^{c}$ & $0.003 \pm 0.00^{\mathrm{b}}$ & 0.50 & 0.20 \\
\hline & $\mathrm{Cr}$ & $0.007 \pm 0.00^{a}$ & $0.010 \pm 0.01^{b}$ & $0.025 \pm 0.01^{d}$ & $0.028 \pm 0.00^{c}$ & 0.50 & 0.50 \\
\hline & $\mathrm{Pb}$ & $0.017 \pm 0.01^{\mathrm{a}}$ & $0.027 \pm 0.03^{c}$ & $0.033 \pm 0.02^{\mathrm{d}}$ & $0.020 \pm 0.02^{b}$ & 2.00 & 2.00 \\
\hline & $\mathrm{Zn}$ & $0.277 \pm 0.02^{\mathrm{d}}$ & $0.026 \pm 0.03^{c}$ & $0.208 \pm 0.01^{a}$ & $0.235 \pm 0.03^{b}$ & 30.00 & 30.00 \\
\hline & $\mathrm{Mn}$ & $0.107 \pm 0.01^{a}$ & $0.130 \pm 0.03^{b}$ & $0.150 \pm 0.08^{c}$ & $0.108 \pm 0.01^{a}$ & 0.50 & 0.50 \\
\hline
\end{tabular}
$\mathrm{kg}$ in H. isopterus.

Table 1. Concentration of Heavy metals in the gill and muscle of fish. 


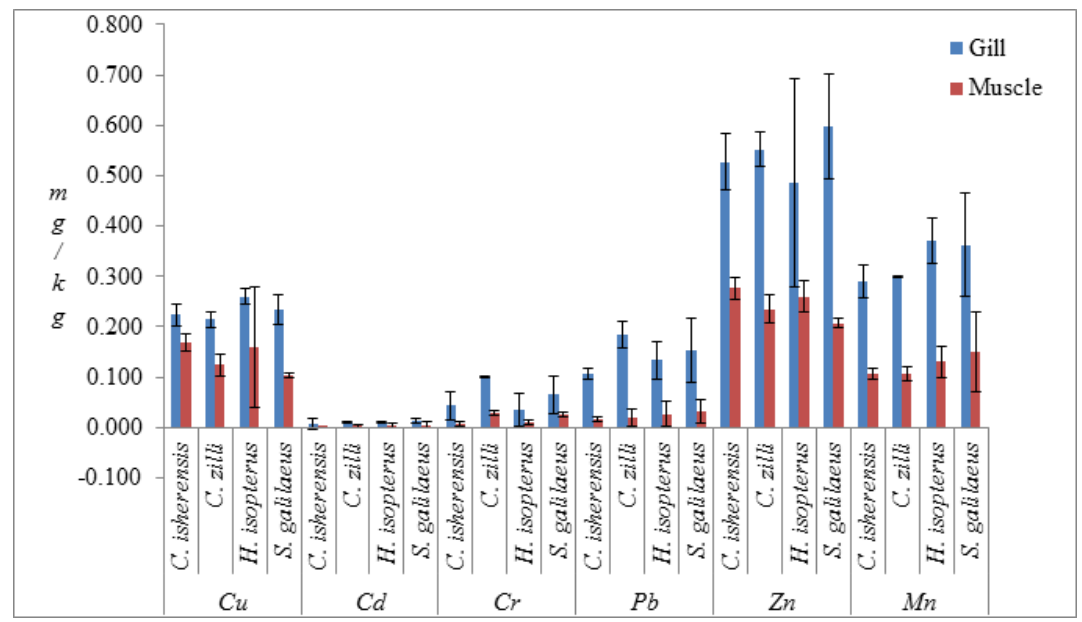

Figure 1. Comparison between the concentration of Heavy metals in Gills and Muscle of fish.

\section{Ecological Risk Quotient (ERQ)}

The ecological quotient of the heavy metals as presented in Figure 2 show that the metals examined had no significant ecological risk as the values of ERQ were below one (1) except for $\mathrm{Mn}$ in H. isopterus (1.00) and S. galilaeus (1.02) which were above the risk limit of one (1).

\section{Health Risk Index (HRI)}

The HRI of the examined metals in all the species (Figure 3) shows that no health risk was associated with the four species as the values were below 1 . Also, Figure 3 revealed that $\mathrm{Pb}$ had the highest values in all the species in the ascending order of C. isherensis $<H$. isopterus $<S$. galilaeus $<C$. zilli while the minimum concentrations were observed in $\mathrm{Cr}$.

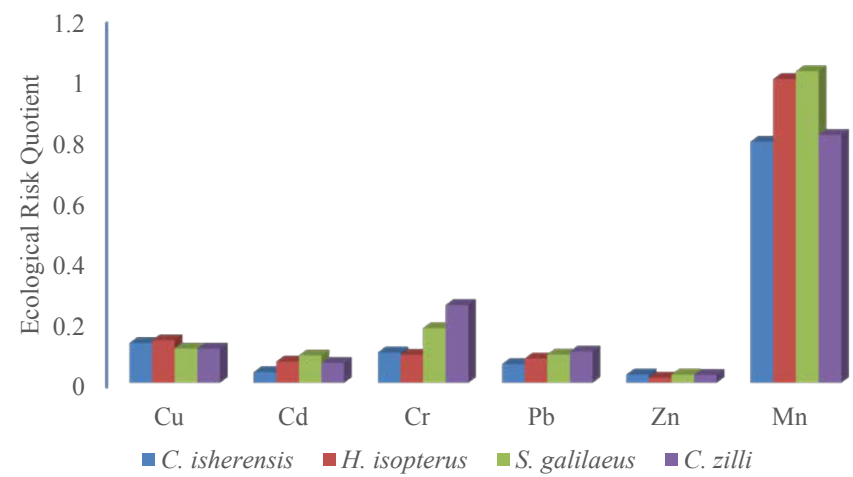

Figure 2. Ecological Risk Index of Heavy Metals in fish species from Awara Reservoir.

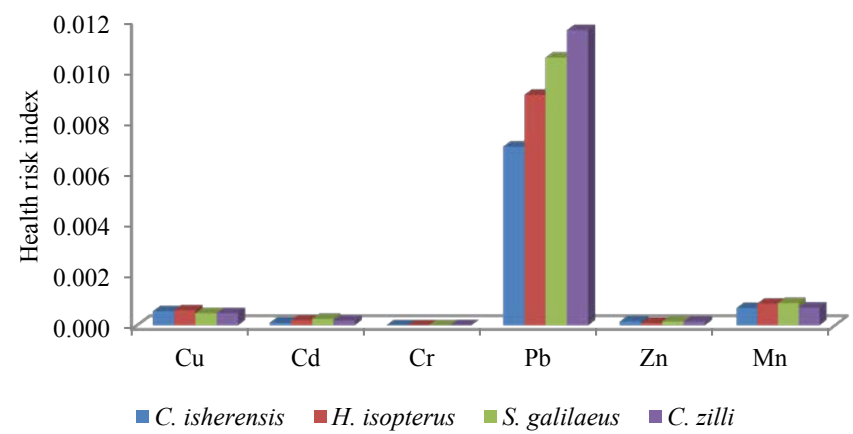

Figure 3. Health risk index of Heavy Metals in fish species from Awara Reservoir.

\section{Discussion}

This study reveals that bio-accumulation of heavy metals occurred in an order of $\mathrm{Cd}<\mathrm{Cr}<\mathrm{Pb}<\mathrm{Cu}<\mathrm{Mn}<\mathrm{Zn}$ for the four species examined and it is similar to the findings of Adedeji and Okocha [14] on M. macrobrachion and M. vollenhovenii from Epe lagoon and Asejire River. This shows that the pattern of accumulation was similar in the four species. Zinc had the highest concentration in the four species, however, the concentration was below the FEPA [13] and FAO [11] permissible limit of 30 $\mathrm{mg} / \mathrm{kg}$. The high zinc concentration recorded in the four species could be adduced to increase in the land-based agrochemical use observed in the study area and the fact that fishes take up zinc directly from water, especially through gills [15]. The generally low concentration of metals in the fishes was not surprising because of the low human activities in the study area.

The analyzed metals were significantly higher $(\mathrm{p}<0.05)$ in the gills than the muscles. This is partly because the gill is naturally endowed with physiological and anatomical properties which must have maximized the absorption efficiency of the heavy metals from the aqueous phase. This is in line with the findings of Eneji et al. [16] and Fafioye et al. [17] from River Benue and Ogun River respectively. Olusola and Festus [1] opined that gill is the organ that accumulates the highest concentration of metals since it is a metabolically active part, being a dominant site of gas exchange and responsible for acid-base balance, ionic-regulation and nitrogenous waste excretion for fishes (and other aquatic organisms) thereby serving a throng of vital functions for these organisms while Adefemi et al. [18] and Eneji et al. [16] reported that muscle does not act as an active tissue in the accumulation of metals. The differences in the accumulation patterns of these minerals in the gills and muscles might be a reflection of their different metabolic pathway. Also, high concentrations of heavy metals observed in the gills than muscles can be attributed to the fact that the gill is constantly involved in physiological functions such as respiration, ion regulation and osmoregulation which entail active interactions with extraneous chemicals [10].

The results also revealed that the pattern for concentration of metals in the species was $C$. isherensis $<H$. isopterus $<$ C. zilli $<S$. galilaeus. The results showed very similar accumulation pattern 
in the two families. However, species belonging to the family Cichlidae exhibited higher concentration of the minerals than Claridae. This could be because the two families possess different attributes in their behavioral and feeding habits. Olaifa et al. [19] opined that bio-accumulation of heavy metals in fishes could also be linked to ingestion and accumulation through the abiotic environment. This observation was similar to the report of Eneji et al. [16] on the bioaccumulation of heavy metals in different organs of C. gariepinus and Tilapia zilli from river Benue.

The results also revealed that the highest metal bioaccumulation was observed in $S$. galilaeus when compared with the other species. This is evident in the results of ecological risk assessment which showed that $\mathrm{Mn}$ posed some ecological risk to $S$. galilaeus and $H$. isopterus. Long term exposure to these heavy metals can result in negative ecological effects such as reduced breeding potential of adult fish and high mortality of juvenile fish of the species [20]. Decrease in organism's fitness, discomfort, disorientation, imbalance, multi-system organs failure and inability to locate food as observed by Roth [20] and Krang and Rosenqvist [21] are some of the ecological implications associated with the high levels of Mn observed in the four examined species. However, the metal concentration in the gill and muscles of $S$. galilaeus (and the three other examined species) were within WHO [12] and FEPA [13] permissible limit.

Despite the ecological risks observed in S. galilaeus and $H$. isopterus, no health risk was observed for the four fish species examined in this study. Although $\mathrm{Pb}$ was below the risk limit, it was very high (when compared with the other metals) in the four species and long term exposure may elicit several implications such as neurological damage in children (hyperactivity, poor attention span, low IQ), declined fertility in males, inhibition and disruption of biosynthesis of haemoglobin thereby leading to insufficient transport of oxygen and anemia in man $[22,23]$. However, the species can be considered fit and safe for consumption, because the health risk index (HRI) were below one (1). Nonetheless, there is tendency of danger in the future depending on the agricultural development and humanmediated activities in the area because of the values observed for $\mathrm{Pb}$ in the four species. There may be potential hazards in the long-run if human-mediated activities in the area are not regularly monitored and controlled.

\section{Conclusion}

The concentration of all the heavy metals in the examined fish species was generally below the permissible limit set by WHO, FEPA and FAO in fish even though all the six metals analyzed were found. This study also established that gills bioaccumulated more metals than muscle in the four examined fish species. Similarly C. zilli and S. galilaeus (Cichlidae) bioaccumulated more metals than $C$. isherensis and $H$. isopterus (Claridae). Findings also showed that no health risk was observed for the consumption of the four fish species but ecological risk was recorded for Mn in S. galilaeus and H. isopterus. Therefore, anthropogenic activities in the area should be regulated to the barest minimum and the fisheries of the area must be constantly checked to improve the fish yield as well as diversity and to ensure healthy fish food for human consumption.

\section{References}

1. Olusola JO, Festus AA. Levels of heavy metals in some selected fish species inhabiting Ondo state coastal waters, Nigeria. J Environ Anal Toxicol. 2015;5:303-14.

2. Hassan Z, Anwar Z, Usman KK, et al. Civic pollution and its effect on water quality of river Toi at District Kohat, NWFP. Research J Environmental and Earth Sciences. 2012;4(5):21-7.

3. Farkas A, Salanki J, Specziar A. Relation between growth and the heavy metal concentration in organs of bream Abramis brama L. populating lake Balaton. Arch Environ Contam Toxicol. 2002;43(2):236-43.

4. Al-Bader N. Heavy metals levels in most available fish species in Saudi market. J Food Technol. 2008;6(4):173-7.

5. Mansour SA, Sidky MM. Ecotoxicological studies. 3. Heavy metals contaminating water and fish from fayoum Governorate, Egypt. Food Chem. 2002;78:15-22.

6. United Nations Industrial Development Organization (UNIDO) 2013. Annual Report Vienna. 2014;76pp.

7. Adesulu EA, Sydenham DHJ. The freshwater fishes and fisheries of Nigeria. Macmillan Nigeria Publishers Limited. Lagos, Nigeria. 2007;397.

8. Olaosebikan BD, Raji A. Field guide to Nigerian freshwater fishes. Revised Edition. Federal College of Freshwater Fisheries Technology. New Bussa. Nigeria. 2013;p:144.

9. Association of Official Analytical Chemicals (AOAC). Official methods of analysis. 16th Edition. AOAC Arlington Virginia. 2006.

10. Isibor PO, Imoobe TOT. Comparative analysis of contaminability between C. gariepinus and T. mariae. Annual Research and Review in Biology. 2017;16(5):1-14.

11. Food and Agricultural Organization (FAO). Fishery profile. The Federal Republic of Nigeria. 2007;p:24.

12. WHO. Evaluation of certain food additives and contaminants. In: Summary and conclusions of the 61st meeting of the Joint FAO/WHO Expert Committee on Food Additives (JEFCA), Rome, Italy. 2003.

13. FEPA. Guidelines and standards for environmental pollution control in Nigeria. Federal Environmental Protection Agency. 2003;p:238.

14. Adedeji OB, Okocha RC. Bioconcentration of heavy metals in prawns and water from Epe lagoon and Asejire River in southwest Nigeria. Journal of Applied Sciences in Environmental Sanitation. 2011;6(3):377-84.

15. Bala BU, Abdullahi IL, Zakari HH, et al. Determination of zinc and lead in surrounding water and gills of Tilapia zilli from 'farfazai' pond in Kano city, Nigeria. Bayero Journal of Pure and Applied Sciences. 2017;10(1):107-11. 
16. Eneji IS, Ato RS, Annune PA. Bioaccumulation of heavy metals in fish (Tilapia zilli and C. gariepinus) organs from river Benue, North-Central, Nigeria. Parkistan Journal of Analytical and Environmental Chemistry. 2011;12(1/2):1-8.

17. Fafioye OO, Oladunjoye RY, Bamidele TT, et al. Determination of heavy metal levels in Oreochromis niloticus and Chrysichthys nigrodigitatus from Ogun River, Nigeria. Int J Fish and Aquac. 2015;9(8):86-91.

18. Adefemi OS, Olaofe O, Asaolu SS. Concentration of Heavy metals in water sediment and fish parts (Illisha africana) from Ureje dam, Ado-Ekiti, Ekiti State, Nigeria. Journal of Biological and Physical Science. 2004;3:111-4.

19. Olaifa FE, Olaifa AK, Adelaja AA, et al. Heavy metal contamination of Clarias gariepinus from a lake and fish farm in Ibadan, Nigeria. African Journal of Biomedical Research. 2004;7:145.
20. Roth JA. Homeostatic and toxic mechanisms regulating manganese uptake, retention, and elimination. Biological Research. 2006;39(1):45-57.

21. Krang AS, Rosenqvist, G. Effects of manganese on chemically induced food search behaviour of the Norway lobster, Nephrops norvegicus (L.). Aquatic Toxicology. 2006;78(3):284-91.

22. Landis $\mathrm{WG}, \mathrm{Yu} \mathrm{M}$. Introduction to Environmental Toxicology: Impacts of chemicals upon ecological systems. CRC Press. Boca Raton. Florida. 2003.

23. Bradl H. Heavy Metals in the Environment: Origin, Interaction and Remediation. Elsevier/Academic Press. London. 2005;p:269.

\section{*Correspondence to:}

Ajibare AO

Department of Biological Sciences

KolaDaisi University

Ibadan

Nigeria

Tel: 08034804486

E-mail: mrajifem@yahoo.com 